\title{
EPIGÊNESE E EPIGENÉIICA: AS MUITAS VIDAS DO VITALISMO OCIDENTAL
}

\section{Gláucia Silva* \\ Universidade Federal Fluminense - Brasil}

Luiz Fernando Dias Duarte ${ }^{* *}$

Museu Nacional, Universidade Federal do Rio de Janeiro - Brasil

Resumo: A análise da história e dos usos contemporâneos dos termos epigênese, atribuído a Aristóteles, e epigenética, criado no século XX pelo biólogo $C$. $H$. Waddington, revela as tensões entre as perspectivas vitalistas e mecanicistas - ou epigenistas e pré-formacionistas - que têm se contraposto regularmente no seio das ciências da vida na cultura ocidental desde o século XVII. O campo demarcado pelo último termo abriga intensas discussões sobre os limites do neodarwinismo, abrindo espaço para a influência do meio na transmissão transgeracional. Essas tensões e polêmicas encontram fundo eco nas ciências humanas, por postularem diferentes pesos e implicações da herança "natural" para a vida mental, social ou cultural no desenvolvimento e efetivação da humanidade.

Palavras-chave: antropologia da ciência, epigênese, evolucionismo, vitalismo.

Abstract: A review of the history and contemporary use of the terms "epigenesis", coined by Aristotle, and "epigenetics", proposed by the biologist C. H. Waddington in the $20^{\text {th }}$ century, brings to light the tensions between the vitalist and mechanist - or epigenist and preformationist - competing tendencies in life sciences in Western culture since the $17^{\text {th }}$ century. Epigenetics involves intense discussions about the limits of neo-darwinism, opening space for the influence of the "environment" in transgenerational transmission. These tensions and polemics are of great interest for the

* Contato: glaucia.o.silva@gmail.com

** Contato:1fdduarte@uol.com.br 
humanities, since they imply different roles for "natural" heritage in mental, social and cultural life through the development and actualization of humanity.

Keywords: anthropology of science, epigenesis, evolutionism, vitalism.

\section{Introduç̃o}

As questões levantadas por Gregory Bateson na década de 1970 sobre a evolução orgânica e o processo de emergência da mente estão sendo hoje retomadas à luz de disciplinas como a epigenética e as neurociências (Bateson, 1986). Contrariamente ao paradigma hegemônico à época, Bateson propunha um retorno à possibilidade da herança dos caracteres adquiridos, associada ao pensamento de Lamarck, em interação com a aleatoriedade característica do modelo darwiniano da evolução natural. Parecia assim retomar o fio da tradição vitalista, em contraponto às teorias pré-formacionistas prevalecentes. As tensões entre perspectivas vitalistas e mecanicistas - ou mais especificamente entre epigenistas e pré-formacionistas - têm um lugar cativo no seio das ciências da vida na cultura ocidental, embora, a cada momento, essas correntes se contraponham com novas nuances. São controvérsias que não se repetem simplesmente; perduram - isto sim - modeladas por marcantes alterações de sentido ao longo do tempo. Reverberam, além do mais, constantemente nas ciências humanas, por postularem diferentes pesos e implicações para a vida mental, social ou cultural no desenvolvimento e efetivação da humanidade.

Tratar-se-á aqui de diversas acepções dos termos epigênese, cunhado por Aristóteles, e epigenética, criado pelo biólogo C. H. Waddington em 1942. O primeiro pode tanto se referir ao processo embrionário (como sinônimo de embriogênese ou de ontogênese) quanto pode designar a teoria de longo curso relativa ao desenvolvimento dos embriões, segundo a qual os seres vivos resultam do desdobramento sucessivo da célula-ovo premida por uma força imaterial.

Já o termo "epigenética" foi criado para substituir "epigênese", no intuito de descrever tanto o processo da embriogênese (ou ontogênese) quanto a disciplina que estuda o desenvolvimento embrionário dos seres vivos, a embriologia. Com o biólogo Robin Holliday, a partir dos anos 1980, ela passou a designar não só uma disciplina, mas toda uma gama de fenômenos empíricos relativos ao funcionamento dos genes nos núcleos das células - como ele

Horizontes Antropológicos, Porto Alegre, ano 22, n. 46, p. 425-453, jul./dez. 2016 
mesmo comenta (Holliday, 2006, p. 78). O postulado mais usual da genética é ainda o de que cada gene é o responsável pela codificação e pela síntese de uma proteína específica. Mas, com as pesquisas sobre clonagem e com o desenvolvimento do Projeto Genoma Humano, os cientistas passaram a concordar que a grande maioria dos genes não tem por função a síntese proteica, atuando especificamente na coordenação dos genes codificantes. $\mathrm{O}$ "epigenoma" veio a designar justamente o conjunto desses genes não codificantes. O Projeto Epigenoma Humano vem estudando atualmente os fenômenos epigenéticos (cf. www.epigenome.org).

Um dos efeitos da coordenação no nível do epigenoma é a possibilidade de silenciar genes ativos e ativar outros que estavam inativos. Essas alterações, que também são chamadas de "mutações epigenéticas", podem ser passadas à descendência, exatamente como uma mutação genética. A percepção de que existe esse tipo de mutação - epigenética - é um "fato científico" relativamente recente; mas ainda estão em discussão as suas consequências para a teoria evolutiva ortodoxa (e, desde os anos 1920, hegemônica), conhecida por neodarwinismo, "teoria sintética" ou ainda "síntese moderna".

Todo esse campo fornece subsídios importantes para o permanente debate, na antropologia social e cultural, sobre a relação entre natureza (enquanto suposto substrato permanente da vida humana, transmissível pelos genes) e cultura (aquilo que se acrescentaria pela experiência social e pelo simbolismo cultural, sendo transmitido pelo aprendizado) - ou sobre a possibilidade de reordenação do binômio ou de sua superação.

O modelo neodarwinista hegemônico desde o começo do século XX é solidário da tradição mecanicista e determinista da linha mestra da ciência ocidental: a realidade existe fora da consciência humana, ela é organizada de um modo que pode ser tornado compreensível pela ciência (o que permite a sua manipulação tecnológica em favor da humanidade), e - máxime - o próprio humano faz parte dela e compartilha de suas características universais.

Essa disposição monista foi continuamente contraditada desde o século XVIII, graças em parte ao dualismo cartesiano entre a extensão e o pensamento; graças por outra parte às próprias críticas ao pensamento de Descartes e à sua mecanização da matéria. Chamou-se de vitalismo a uma determinada direção dessas críticas, também monista no limite, embora apoiada no princípio oposto ao da matéria. As versões de afirmação de um "princípio vital”, garantia do espírito englobante do universo, foram muito variadas, fornecendo parte 
da argumentação do "organicismo" que, nas ciências biológicas e médicas, acabou nuançando o universal mecanicismo (cf. Gusdorf, 1974; Reill, 2005). Veremos como esse vitalismo esteve relacionado no século XVIII à oposição ao modelo pré-formacionista da gênese humana, associável a uma disposição mais fisicalista e determinista.

Na segunda metade do século XIX, a afirmação progressiva das ciências humanas se deu sob inspiração da filosofia romântica, em cujo âmbito se desenvolvia o vitalismo, ao lado do idealismo e do historicismo. ${ }^{1} \mathrm{O}$ traço comum a essas outras ciências seria justamente o da defesa da impossibilidade de examinar a experiência humana com os mesmos parâmetros e instrumentos das ciências naturais e experimentais. Essa disposição ora se concentrou na elaboração de teorias baseadas na liberdade de ação e no dinamismo específico dos sujeitos individuais, na tradição do liberalismo iluminista, ora se concentrou na postulação de ordens de determinação abrangentes, como a cultura, a sociedade ou o psiquismo, na tradição do holismo romântico. Num e noutro plano, prevalecia a ênfase na recusa de um determinismo linear da natureza ou da dimensão física do humano.

O modelo da evolução proposto por Darwin, apesar de seu diálogo com as teorias individualistas e utilitaristas de Spencer, pesou fortemente na balança entre as duas disposições científicas, permitindo que uma redução materialista radical pudesse ganhar terreno, nutrindo-se da ideia da seleção natural como um determinismo físico. As teorias da evolução natural, cujo peso se tornou ainda maior com a estabilização do neodarwinismo no começo do século XX, continuaram a se apresentar como uma alternativa às teorias socioculturais e psicodinâmicas, tendo se cristalizado em uma sociobiologia e, mais recentemente, em uma antropologia e uma psicologia "evolucionárias".

Por outro lado, os desenvolvimentos mais recentes da antropologia vêm incluindo com cada vez mais ênfase a noção de "vida" como um recurso analítico (e não apenas como um termo descritivo) (cf. Ingold, 2006, 2013), o que exige um esclarecimento de sua emergência como categoria central da cosmologia ocidental moderna (cf. Duarte, 2012), em boa parte graças à luta do vitalismo contra os determinismos "materialistas".

1 É o período em que se institucionaliza a oposição sistemática entre as "ciências da natureza" e as "ciências do espírito" (ou "morais") - cf. Gusdorf (1974).

Horizontes Antropológicos, Porto Alegre, ano 22, n. 46, p. 425-453, jul./dez. 2016 
O desenvolvimento de uma epigenética, entendida como parte de um processo evolutivo que admite a transmissão transgeracional de caracteres adquiridos na experiência ontogenética dos indivíduos em relação com o seu meio ambiente, permite retomar em novas bases as propostas pioneiras de Gregory Bateson. A possibilidade de uma releitura vitalista de alguns aspectos da obra do próprio Darwin acompanha as propostas mais recentes de Tim Ingold (1990, 2004, 2006, por exemplo), relativas à imbricação entre o que a cultura hegemônica ocidental opôs como uma natureza e uma cultura. ${ }^{2}$

\section{Vitalismo e epigênese}

Canguilhem observa que a história natural e as ciências biológicas se constituíram como um pensamento dividido e oscilante entre duas visões concorrentes, conhecidas por mecanicismo e vitalismo, que se defrontam em diferentes níveis e por meio de diferentes antinomias: estrutura e função; continuidade e descontinuidade; forma, pré-formação e epigênese; atomicidade e totalidade; desenvolvimento do ser e individualidade (Canguilhem, 2012, p. 87). A permanência dessa oscilação evidencia que ambas as correntes levantam questões suficientemente importantes para perdurarem. Simpático ao vitalismo, Canguilhem analisa as diversas feições que essa perspectiva veio assumindo desde Aristóteles, argumentando que há entretanto algo em comum que justifica a reunião de teorias e técnicas medicinais e científicas tão diversas, surgidas e praticadas ao longo de milênios, sob esse mesmo epíteto. A premissa de todos os vitalismos, comum a filósofos e outros pensadores cujas contribuições conformam a história natural, as ciências médicas e as ciências biológicas, é a de que existiria algo equivalente a um princípio vital, responsável pela diferença entre um ser bruto e um ser vivo.

As observações de Aristóteles sobre o ovo e o desenvolvimento embrionário dos animais originaram a teoria que ele chamou de "epigênese", para dar conta do surgimento de um novo ser vivo. A epigênese aristotélica postulava

\footnotetext{
2 As reflexões aqui presentes foram inicialmente debatidas em um curso ministrado pelos autores em 2012, que reuniu alunos de seus dois programas de pós-graduação, e num segundo, de responsabilidade de Silva, ocorrido em 2014, no PPGA/UFF, dando sequência a algumas de nossas comuns inquietações anteriores. Neste último curso, a aluna Karine Narahara, da UFRJ, merece agradecimento pela contribuição à discussão.
}

Horizontes Antropológicos, Porto Alegre, ano 22, n. 46, p. 425-453, jul./dez. 2016 
que o surgimento de um novo ente ocorria gradualmente a partir da ação de um princípio a que denominou "alma", capaz de transformar uma porção de matéria inicial em uma forma organizada e dotada de funções vitais. A influência dessa teoria se estendeu até o século XVIII, quando os novos pressupostos epistemológicos relativos à observação empírica - mediada por engenhos tais como o microscópio, surgido no século anterior - foram legitimados, sem nunca rechaçarem totalmente a aceitação da epigênese, numa modalidade de vitalismo, isto é, a assunção de uma "força vital" ou "alma" presidindo o fenômeno da vida.

Canguilhem et al. (2003) consideram que os mecanicistas, em oposição aos vitalistas, tinham em comum entre si a recusa de princípios abstratos, tais como a existência de alma (ou germe), supostamente responsável pelo funcionamento dos organismos vivos. Os mecanicistas assumiam que somente os mecanismos demonstráveis poderiam ser levados em conta na explicação da vida como fenômeno; e os nomes de Descartes, Newton e Virchow foram invocados como exemplos desse bom método. As explicações materialistas ou mecanicistas postulavam que os seres vivos se originavam de moléculas orgânicas ${ }^{3}$ e defendiam que o surgimento de novos seres era resultante de uma aposição ou justaposição de elementos. Prescindiam, assim, da figura do "princípio vital" ou da "pré-formação" do ser; mas não conseguiam explicar como se originavam da matéria amorfa seres organizados em totalidades preocupação central para os vitalistas.

Essa interpretação se distingue, em alguma medida, daquela em que se baseia o neurobiólogo Richard Francis (2011). Francis reflete a visão mais consensual dos filósofos e historiadores da ciência de que a corrente de pensamento conhecida por pré-formacionismo, que se opôs à epigênese e que conheceu grande expansão no século XVIII, constituiu uma modalidade de mecanicismo. Entretanto, epigenistas e pré-formacionistas acreditavam na existência de um "germe"; a principal diferença sendo que, para os primeiros, esse germe se desenvolveria graças a uma força vital e não conteria todas as estruturas que evoluiriam (ou cresceriam) na direção de um novo ser. Haveria uma formação sucessiva das diferentes partes do organismo cujo conjunto

3 A teoria materialista sobre o início da vida conhecida como "geração espontânea" só veio a ser experimentalmente desautorizada no século XIX.

Horizontes Antropológicos, Porto Alegre, ano 22, n. 46, p. 425-453, jul./dez. 2016 
constitui o corpo do embrião. Já para os segundos, o germe de um minúsculo ser (um "homúnculo" ou "animálculo"), pré-formado no interior do ovo, seria o responsável pela origem do novo ser vivo. Por esse motivo, Canguilhem et al. (2003) consideram tanto os adeptos da epigênese quanto os do pré-formacionismo que vigorou antes de Darwin como vitalistas. Tendo ocorrido grande variedade de visões pré-formacionistas nos séculos XVII e XVIII, entendê-las como mecanicistas implicaria maior simplificação de suas teorias do que reconhecer o denominador comum da crença em algo que já está presente no ovo e é responsável pelo surgimento do novo ser.

Esses autores chamam a atenção ainda para a importante mudança de sentido por que passou a ideia de epigênese entre os séculos XVIII e XX, bem como se alteraram os significados das noções de evolução e de desenvolvimento no período que separa a Teoria das gerações de C. F. Wolf, publicada em 1759, de A origem das espécies de Charles Darwin, em 1859. Explicam que os termos "evolução" ou "desenvolvimento", ao longo do século XVIII e primeira metade do século XIX, se referiam estritamente ao desenvolvimento do ovo, ao nascimento de um ser vivo, nada tendo a ver com a "evolução das espécies". As acepções daqueles termos compunham um ideário muito heterogêneo, atravessado por discordâncias entre pensadores como Malebranche e Leibniz (citados como teóricos pioneiros da evolução - Canguilhem et al., 2003, p. 13), e ainda A. von Haller, C. Bonnet, Buffon e Lamarck. Assim, ao longo daquele primeiro período, coexistiram três tendências explicativas do processo de surgimento de um novo ser: a evolucionista (ou desenvolvimentista ou pré-formacionista), a epigenista e a materialista. A epigênese e a visão evolucionista eram, como já se viu, para Canguilhem et al. (2003), explicações vitalistas do desenvolvimento do ovo.

Os conceitos de desenvolvimento e de evolução, nos séculos XVII e XVIII, não só eram semanticamente equivalentes, por se referirem ao crescimento de um ser pré-formado, como se opunham às explicações mecanicistas (ou materialistas) sobre a origem de um novo ser vivo. A noção de um corpúsculo, defendida pelos evolucionistas pré-formacionistas, apresentava, aos olhos de seus críticos mecanicistas, grande afinidade com a Criação Especial. A teoria evolucionista, àquela altura, não entrava em choque com as premissas do criacionismo; ao contrário, era a hipótese do germe original dotado de princípio vital que sofria generalizadas críticas, ora por sua falta de cientificidade, ora por ser potencialmente questionadora da cosmologia cristã. Implicava a 
ideia de que haveria algo de imaterial em toda parte, podendo ensejar o surgimento de novos seres: "A ideia de epigênese remete àquela de omnigênese e contradiz a Gênese" (Canguilhem et al., 2003, p. 16, tradução nossa).

Segundo Canguilhem et al. (2003, p. 63, tradução nossa) foi apenas sob a influência da teoria de Darwin que a palavra "evolução" abandonou o plano do desenvolvimento dos embriões para abarcar o do transformismo, havendo a "subordinação do conceito de epigênese ao conceito de evolução das espécies". Os autores chamam a atenção para o fato de Darwin ter acrescentado a dimensão geográfica à anatômica e à embriológica, em sua formulação de espécie (ou de variedade), graças ao seu trabalho de campo (Canguilhem et al., 2003, p. 64-65). No entanto, para Darwin, as áreas geográficas não poderiam proporcionar nada além de equilíbrios provisórios para seus habitantes. Desse modo, as espécies compostas de indivíduos sempre diferentes uns dos outros (ainda que ligeiramente) seriam, para o naturalista, unidades dinâmicas. Canguilhem et al. argumentam que, assim como a visão epigenista pressupunha a ideia de "tipo", quer dizer, de algo cuja marca seria a fixidez de certas características, a mudança de significado de evolução acabou impondo a nova ideia da "espécie", como um conjunto que muda ao longo do tempo.

Darwin não foi um estudioso da embriologia, mas usou os estudos de Hæckel para evidenciar sua conviç̧ão na origem comum de todos os seres vivos. Graças a seu apreço, no entanto, pela referência às totalidades, é considerado epigenista por Canguilhem e também por Francis (2011). O neodarwinismo, todavia, não pode ser assim caracterizado, devido à influência das propostas de Gregor J. Mendel e de August Weismann; ${ }^{4}$ decisiva, esta última, para a identificação da "teoria moderna" como pré-formacionista. Na última década do século XIX, Weismann estabeleceu que um organismo se originava de uma única célula fertilizada, em cujos cromossomos se encontraria toda a informação necessária para a origem do novo ser. O pré-formacionismo de Weismann estabeleceu ainda que era exatamente o núcleo de cada célula a sede de onde emanavam as determinações para sua função e estrutura, a salvo

\footnotetext{
4 Weismann refutou claramente a possibilidade de "herança dos caracteres adquiridos", sustentada por Lamarck, ao estabelecer que somente as alterações ocorridas nos cromossomos das células germinativas (ou gametas) poderiam ser passadas à descendência e que as alterações nos cromossomos das células somáticas não eram herdáveis pelos descendentes.
} 
de qualquer alteração ensejada a partir de seu exterior, ou seja, de qualquer outro ponto do citoplasma ou de fora da célula.

Uma outra análise que enriquece a de Canguilhem et al. (2003) e auxilia a entender por que a noção de evolução passou a designar a transformação das espécies e não mais o desenvolvimento do ovo é a de Robin Holliday (2006). Ele explica que, ao longo do século XIX, os estudos sobre herança dos caracteres legados à descendência, ou seja, o que chamamos hoje de genética, não eram dissociados de pesquisas sobre embriologia (ou desenvolvimento ontogenético), e endossa a hipótese de que Gregor Mendel não teve a importância de seu trabalho imediatamente reconhecida devido ao fato de ter se restringido ao estudo do processo de herança. Só nos primeiros anos do século XX, 30 anos após os estudos de Mendel, a genética viria a ganhar impulso, ao retomar os seus trabalhos pioneiros.

Canguilhem et al. (2003) remetem basicamente a Darwin quando explicam a transformação da noção de evolução na passagem do século XIX para o XX. É certo que sua interpretação está atenta à mudança de significado do conceito e ao desprestígio sofrido à época pela visão vitalista, mas o deslocamento de enfoque da embriogênese para o transformismo parece ter sido menos uma consequência direta das colocações de Darwin do que o fruto de uma reapropriação de suas ideias por cientistas que, nos laboratórios, conseguiam meios experimentais de compreensão do funcionamento do núcleo do ovo, a organela que parecia ditar suas sucessivas divisões celulares (cf. Holliday, 2006).

A hipótese da existência dos genes como entidades responsáveis pelas características hereditárias ensejou algo que, até então, parecia contraditório: uma variedade de pré-formacionismo isenta da pecha de vitalismo. A chancela científica foi certamente causa e efeito do sucesso da genética, que demonstrou grande habilidade para se expressar em termos mecanicistas, ao passo que o mesmo não ocorreu nem com a embriologia nem com a biologia do desenvolvimento, conforme atesta a análise de Donna Haraway (2004) sobre o processo pelo qual a representação do organismo como uma máquina foi substituída pela metáfora do organismo como um sistema ("orgânico"), na primeira metade do século XX. Embriologistas e biólogos do desenvolvimento tiveram dificuldades em instrumentalizar suas disciplinas segundo os cânones do mecanicismo contemporâneo, devido ao desafio representado pelos experimentos de Hans Driesch, dentro do programa de pesquisa de Wilhelm 
Roux - ambos importantes cientistas mecanicistas empenhados em derrubar experimentalmente o vitalismo.

O objetivo dessas experiências era a verificação de hipóteses sobre a embriogênese animal, realizando experimentos com vários animais, entre eles ouriços-do-mar. Para Roux, se as duas células resultantes da primeira divisão celular, ocorrida depois da fecundação, fossem separadas, cada célula originaria meio ouriço-do-mar. Esse resultado comprovaria o pressuposto materialista-pré-formacionista, partilhado tanto por Roux quanto por Driesch, de que não haveria princípio vital presidindo o desenvolvimento embrionário de um ser vivo. Roux acreditava que quando a célula-ovo, que se supõe conter toda a informação necessária para o crescimento do novo ser, se dividisse em duas, o conjunto original das informações seria distribuído entre elas, e assim sucessivamente, de forma que, ao final da formação do organismo, cada célula possuiria apenas uma parte das informações iniciais, conforme suas funções específicas.

Driesch conseguiu realizar a separação das duas células resultantes da divisão do zigoto; entretanto, cada uma originou um ouriço inteiro e normal, para surpresa do cientista. Driesch também manipulou o embrião e deslocou algumas células da parte dorsal (dos espinhos) para a ventral, que fica em contato com o solo; e deslocou para cima algumas células ventrais, que dão origem à boca. Mais uma vez o ouriço originado veio a ser normal, sem espinhos no ventre nem boca no dorso. As células deslocadas funcionavam, portanto, de acordo com uma lógica geral determinada pelo local para onde foram deslocadas experimentalmente. Driesch entendeu que o embrião se desenvolvera segundo uma hierarquia estabelecida pela totalidade; abandonou então suas ideias pré-formacionistas iniciais e postulou a existência de uma força diretora do desenvolvimento dos seres vivos, a que denominou "enteléquia", endossando as ideias vitalistas que pretendia inicialmente contradizer. Não só a surpresa dos resultados experimentais, mas também o rigor lógico com que Driesch, o recém-convertido neovitalista, os interpretava, exigiram esforços suplementares dos cientistas do início do século XX para uma formulação materialista do fenômeno (Haraway, 2004).

Em 1942, o embriologista e geneticista britânico C. H. Waddington criou o vocábulo "epigenética" para substituir o de epigênese, com o intuito de descrever o processo de embriogênese (ontogênese), mas também seu próprio campo de pesquisa, a embriologia. Contrário ao pré-formacionismo, 
corrente já hegemônica à época, e livre das premissas que antes permitiam identificá-la com o vitalismo, Waddington acreditava que o desenvolvimento embriológico através do qual a célula resultante da união de gametas origina um ser deveria ser entendido como um ato de vir a ser, uma construção de algo novo sobre um estágio anterior: "a suitable name for the branch of biology which studies the causal interactions between genes and their products which bring the phenotype into being" (Waddington, 1968 apud Francis, 2011, p. 179).

A criação de um novo termo para designar seu próprio campo de estudos e o fenômeno em si pode ter sido um esforço para desembaraçá-los da aura de misticismo que acompanhava a epigênese, condenando-a à condição de visão "anticientífica". Mas Waddington, segundo Holliday (2006, p. 76), almejava também a unidade das duas disciplinas - embriologia e genética - no interior das ciências biológicas.

Se a visão pré-formacionista, para a qual o desenvolvimento do ovo é apenas o desdobramento de algo que já está lá, passou a ser hegemônica nas ciências biológicas do século XX, foi graças à ideia de genes entendidos como estruturas reais, cientificamente aceitáveis e dotadas de capacidade de execução autônoma em relação ao ambiente externo. Entretanto, Bateson (1986, p. 54-55) comenta que o desenvolvimento do ovo, sob a ótica do pré-formacionismo, não passa de uma complexa tautologia, uma vez estabelecidos os axiomas e definições da evolução. Assim, como Canguilhem et al. (2003) apontaram, os genes passaram a exibir tal valor explicativo que a embriologia saiu do centro da cena científica para dar lugar à ideia de seleção natural, de evolução das espécies sob o efeito das frequências genéticas.

\section{Mutacão genética, conceito-chave do neodarwinismo; mutação epigenética, nova chance para Lamarck}

Alguns pesquisadores, entre eles Ernest Mayr, Theodosius Dobzhansky e George Gaylord Simpson, elaboraram, ao longo das primeiras décadas do século XIX, a teoria conhecida como "sintética" (ou "síntese moderna" ou "neodarwinismo"), que goza ainda hoje de uma aceitação praticamente unânime no campo das ciências biológicas e das ciências sociais (cf. Silva, 2012). A evolução das espécies, ou seja, o processo através do qual a multiplicidade 
de formas vivas hoje existentes teria surgido, é explicada então pela associação do legado de Charles Darwin à genética posterior. A teoria sintética moderna sustenta ainda um dogma central, formulado pelo geneticista F. Crick, muito inspirado nas ideias de Weismann, e também na ideia darwinista de que o mundo vivo se diversifica devido a mutações genéticas aleatórias, acumuladas pelos organismos graças à ação da seleção natural. A aleatoriedade que preside o processo evolutivo passou para a história da biologia como sendo a grande diferença entre a proposta do naturalista vitoriano e aquela de seu antecessor, Jean-Baptiste de Lamarck, para quem as modificações por que os seres vivos passam seriam dirigidas pelo meio, passando as características incorporadas a ser transmitidas aos descendentes. A visão de Darwin defende o oposto: o papel mais importante do "meio" no processo evolutivo não seria o de induzir o surgimento de características, mas o de selecionar aquelas que fossem vantajosas para a sobrevivência de seu portador. Aparecendo sempre de forma aleatória, cada pequena variação que acomete um indivíduo faz dele um ser singular (Darwin, 2004a). A ideia de que o surgimento de uma nova espécie seja resultado de mudanças genéticas aleatórias e acidentais tem sido tratada pelos cientistas como um princípio inquestionável. As mutações genéticas são conhecidas e estudadas desde o final do século XIX, tendo o importante papel na teoria neodarwinista de constituírem a fonte da variabilidade sobre a qual a seleção natural atua.

As mutações genéticas constituem uma alteração na ordem das bases nitrogenadas, as estruturas químicas que formam os genes, com a modificação do formato e do funcionamento dos mesmos e, consequentemente, das proteínas que sintetizam. Tais mutações podem decorrer de eventos espontâneos, como eventuais imperfeições ocorridas no momento de cópia do DNA, ou de danos causados por substâncias da própria célula. Ocorrem, entretanto, com pouca frequência, exceto quando agentes externos (a radiação, por exemplo) atuam de forma sistemática. Há mecanismos comuns de proteção e reparação para compensar possíveis erros no momento da cópia do DNA (Jablonka; Lamb, 2010, p. 111). Além disso, as mudanças desvantajosas tendem a ser eliminadas; as incorporadas pelos seres vivos ao longo do processo de evolução biológica são justamente aquelas que aumentariam a aptidão dos seus portadores.

Assim, pesquisas que, nas décadas de 1940 e 1950, como a de Barbara McClintock, apontavam para a existência de mutações genéticas não aleatórias,

Horizontes Antropológicos, Porto Alegre, ano 22, n. 46, p. 425-453, jul./dez. 2016 
eram tidas como heterodoxas por grande parte da comunidade científica. McClintock, entretanto, foi laureada em 1983, por seu trabalho experimental em citogenética, com o Prêmio Nobel de Fisiologia e Medicina. A equipe de McClintock propôs a existência de elementos móveis (também conhecidos por genes saltadores ou transpósons ${ }^{5}$ ), que mudam de um lugar para o outro no genoma. Além de ter proposto a existência dessa estrutura, a pesquisadora observou que o estresse ambiental levava a um deslocamento maciço desses elementos móveis dos genomas das plantas, sugerindo que as células mobilizam sistemas que alteram seu DNA quando não conseguem responder ao estresse com eficiência. A "descoberta" dos transpósons fez com que McClintock merecesse o prêmio, mas sua interpretação, baseada na observação desses genes saltadores, de que o genoma seria uma organela celular extremamente sensível, frequentemente em processo de reestruturação e de monitoramento das atividades citoplasmáticas e genéticas, assim como de correção de erros comuns e de resposta a eventos incomuns, não foi muito bem aceita (Jablonka; Lamb, 2010, p. 114).

Também nos anos 1980, a equipe do biólogo John Cairns afirmou ter encontrado mutações dirigidas em bactérias e a da bióloga Bárbara Wright encontrou mutações não aleatórias na bactéria $E$. coli. Essas bactérias possuem genes para a produção de determinado aminoácido, que também pode ser obtido quando a bactéria se alimenta. Há bactérias que possuem um defeito no gene que fabrica esse aminoácido, exigindo que absorvam, do meio, maior quantidade de nutrientes. Quando a pesquisadora diminuiu drasticamente a oferta do aminoácido para as bactérias com genes defeituosos, observou um grande aumento na taxa de mutação genética justamente nos genes defeituosos responsáveis pela produção do aminoácido, o que foi interpretado por Wright como uma tentativa de ampliação das chances de a bactéria encontrar a "mutação certa" que lhe permitisse sobreviver. Há, igualmente, evidências experimentais de que, algumas vezes, as mutações genéticas ocorrem em locais precisos do DNA e estão sob controle do ambiente, não ocorrendo portanto aleatoriamente; elas acometem certas regiões do genoma denominadas, no jargão genético, de "pontos quentes" mutacionais, justamente por terem uma

5 Ågren e Stephen (2011) e Lippmann et al. (2004) são exemplos de trabalhos esclarecedores sobre transpósons.

Horizontes Antropológicos, Porto Alegre, ano 22, n. 46, p. 425-453, jul./dez. 2016 
taxa de mutação muito mais elevada em comparação ao conjunto dos cromossomos (Jablonka; Lamb, 2010, p. 121).

A interpretação dada pelo mainstream das ciências biológicas para essas pesquisas é que a célula sob estresse perde sua capacidade de manter o DNA estável por falta de material, e começa a produzir, por isso, mutações em maior número. $\mathrm{O}$ que essas pesquisas destoantes teriam verificado seria um estado patológico e não uma estratégia bioquímica regular, com possíveis consequências para a "adaptação ao meio" (Jablonka; Lamb, 2010, p. 120). Explicar a ocorrência de mutações dirigidas por um estado patológico, ao invés de imaginá-lo como um dispositivo fisiológico comum, permite salvaguardar o dogma central. Entretanto, há darwinistas que, sem questionarem totalmente a validade do neodarwinismo e da importância evolutiva do mecanismo de seleção natural, defendem a hipótese de tais mutações genéticas serem adaptativas; em outras palavras, de terem relevância para a explicação da evolução biológica, exigindo alguma revisão das premissas do neodarwinismo. As "mutações genéticas dirigidas" entram em conflito com o dogma central porque este defende a impossibilidade de haver um fluxo de informação que vá do meio externo em direção ao DNA, de modo a alterá-lo e aumentar, consequentemente, as chances de sobrevivência do organismo. O dogma central proclama a existência de um fluxo unidirecional que parte do DNA para formar uma proteína.

Os biólogos consideram que um gene forma uma proteína, mas nenhuma proteína tem a capacidade de formar um gene. Em outras palavras há tradução, mas não há "retrotradução". Essa fórmula estrutura o dogma central. Outra forma de expressá-lo é afirmar que adaptações ocorridas durante o desenvolvimento de um ser em resposta às condições de vida não podem afetar o que é transmitido à geração seguinte. Embora a "retrotradução" nunca tenha sido observada experimentalmente, nem mesmo quando foram descritas mutações dirigidas, as mutações epigenéticas podem ser a via da transmissão à descendência de caracteres adquiridos, ou seja, a porta que se abre ao lamarckismo como um "palpite fundamentado", nos termos de Jablonka e Lamb (2010).

As mutações epigenéticas ocorrem de maneira bem diferente das genéticas. Elas são produto do silenciamento ou ativação de um gene e não da alteração na ordem das bases nitrogenadas; elas apenas ligam e desligam os genes. Além disso, as mutações epigenéticas são sempre dirigidas, dando resposta a mudanças do meio. Algumas formas de mutação epigenética podem 
passar à descendência, funcionando como uma mutação genética; mas, diferentemente dessas últimas, elas podem ser reversíveis. O termo "epigenética", aplicado a esse tipo de mutação, pouco guarda então do sentido proposto por Waddington. ${ }^{6}$

Passou-se assim de uma especialização disciplinar ocupada com o desenvolvimento do embrião após o processo da concepção, para uma especialização voltada para o desenvolvimento de processos genéticos que ocorrem após o surgimento dos organismos individuais. $\mathrm{O}$ que está sendo chamado atualmente de "mutação epigenética" é um conjunto de fenômenos que poderia estar na origem de muitas doenças e perturbações das espécies naturais. Esses fenômenos dão margem a muitas novas interpretações sobre o funcionamento da célula e dos organismos e poderiam até vir a explicar a eficácia de procedimentos tidos como heterodoxos pela medicina ocidental (como a acupuntura) ou desvendar os mecanismos psicossomáticos indutores de doenças metabólicas e degenerativas (cf. Tost, 2010). Como a má nutrição e a poluição ambiental são fontes de mudanças epigenéticas desvantajosas, há sociólogos que querem aí identificar o elo que propiciaria a desejada interação entre as ciências naturais e as sociais (Landecker; Panofsky, 2013). Jablonka e Lamb (2010) denominam as mutações epigenéticas de mutações "interpretativas", já que não são aleatórias e respondem a alterações no meio e nas condições de vida das células ou organismos. Elas são encontradas especialmente em bactérias, mas ocorrem também em células de animais superiores.

Richard Francis (2011) ilustra o modo pelo qual uma mutação epigenética opera, ao analisar os efeitos de um episódio ocorrido no fim da Segunda Grande Guerra, o da fome que vitimou grande parte da população rural da Holanda ocidental, sob a ocupação alemã. Os descendentes das mulheres que sobreviveram à guerra integram, desde aquela época, uma amostra para estudos sobre os efeitos da inanição materna sobre os fetos. Aos 50 anos, homens e mulheres que estavam no útero de suas mães durante o período de fome apresentaram doenças cardíacas, hipertensão e diabetes do tipo II em maior proporção do que a média da população. As meninas cujas mães sofreram fome no primeiro trimestre de gravidez tiveram mais tendência ao câncer de

${ }^{6}$ No blog do biólogo lamarckista Eduardo B. Sequerra é possível ter fácil acesso ao artigo de Robin Holliday (2006, p. 76) em que ele descreve como retomou o termo criado por Waddington - epigenética - para definir o que ele próprio veio a investigar - cf. http://biologiadoenvolvimento.blogstop.com.br.

Horizontes Antropológicos, Porto Alegre, ano 22, n. 46, p. 425-453, jul./dez. 2016 
mama; as que foram expostas à subnutrição no segundo trimestre de gestação apresentaram maior incidência de problemas nos pulmões e rins. Como explicar os efeitos sentidos na fase adulta de situações que existiram apenas na vida intrauterina? E, mais, como explicar que netos e netas das grávidas em questão também exibam as mesmas tendências de seus pais?

Os pesquisadores observaram que o surgimento da diabetes ocasionada pelas privações alimentares do feto estava correlacionado a genes que funcionavam de forma atípica em células do fígado. Os resultados da pesquisa indicaram que o que fazia a diferença entre o funcionamento dos organismos dos holandeses que não haviam experimentado essa privação e os daqueles que a sofreram não era a presença de genes diferentes, pois os genes não variavam de pessoa para pessoa. O que variou foi o estado de ativação dos mesmos. A inanição materna e, consequentemente, a do feto, estimulou a atividade de genes que normalmente seriam inativos (Francis, 2011, p. 1-8).

A ativação ou o silenciamento dos genes através de processos bioquímicos intracelulares constituem um importante processo regulatório que acontece graças a três processos bioquímicos: metilação genética, metilação de histonas e interferência de RNAi. O estudo sobre a "fome holandesa" verificou que, sendo o estado de silenciamento de certos genes o responsável pela tendência a certas doenças apresentadas pela primeira geração nascida logo após o período de fome, o modo silencioso foi mantido pelos genes ao longo de toda a vida dos indivíduos, sendo, inclusive, passado à descendência. Isso tudo sugere um importante papel desempenhado pelo ambiente sobre o DNA das células do feto (Francis, 2011, p. 43).

Os biólogos estão encarando os resultados dessas pesquisas em epigenética de maneiras diversas. Jablonka e Lamb (2010), por exemplo, sustentam que esse novo entendimento do funcionamento dos cromossomos questiona, parcialmente, o neodarwinismo, na medida em que traz de volta à cena as ideias de Lamarck. Outros cientistas (e.g. Godfrey-Smith, 2007) nela veem uma importante alternativa para o avanço da medicina, já que, por exemplo, a interação entre os sistemas genético e epigenético no desenvolvimento de alguns tipos de câncer é hoje amplamente aceita; sem entretanto concordarem com o "potencial evolutivo" desse mecanismo. A existência de um tipo de mutação dirigida questiona o pressuposto de que a evolução biológica repousa estritamente sobre uma base estocástica e, como afirmam Jablonka e Lamb (2010, p. 103), a "ideia de que novas variantes genéticas - as mutações - pudessem 
ser produzidas especificamente onde e quando fossem necessárias tem sido considerada uma heresia lamarckista". Para se avaliar o impacto que a mutação epigenética pode ter na recuperação das ideias de Lamarck é preciso não descuidar da distinção entre a descrição de um fenômeno e sua aceitação pelos cientistas como um "fato científico". Entre um e outro há todo um processo de "endurecimento" (cf. Latour, 2000), que ocorre frequentemente em meio a controvérsias sobre seu estatuto de matter of fact e também sobre o que esse "fato" representa para as teorias em vigor. A percepção de que existe um tipo de mutação denominada "epigenética" é um "fato científico" relativamente recente e vem trazendo, desde a última década, mudanças no rumo das pesquisas da genética e nas explicações sobre a herança do material genético (ou DNA), mas a interpretação das consequências gerais para o neodarwinismo parece longe de alcançar consenso.

As mutações epigenéticas também constituem um caminho para se compreender o processo de epigênese, ou seja, de diferenciação (ou especialização) celular. São as mutações epigenéticas que podem explicar como, de uma única célula-ovo, surge um novo ser. Também ajudam a formular mais claramente como os bilhões de células de um ser vivo, de conteúdo genético idêntico, adquirem formatos e funções tão distintas. Os cientistas também atribuem aos sistemas epigenéticos a manutenção da "memória celular", ${ }^{7}$ graças à qual as linhagens de células-filhas mantêm as mesmas características da célula-mãe, como garantia da evolução de um desenvolvimento complexo (Jablonka; Lamb, 2010, p. 299-300). Jablonka e Lamb argumentam que a mutação epigenética pode ter tido um papel evolutivo tão importante quanto a mutação genética sob o efeito da seleção natural que, assim, não agiria inteiramente às cegas, mas "em resposta às condições de vida" (Jablonka; Lamb, 2010, p. 129).

Jablonka e Lamb querem conciliar darwinismo e lamarckismo no intuito de dedicarem ao "meio" e ao aprendizado a importância que consideram devida no âmbito da teoria evolucionista. Elas procuram explicar as causas das transformações e adaptações dos seres vivos, de modo a incluir também aí o surgimento da mente (ou capacidade simbólica) específica da espécie humana.

\footnotetext{
7 A propósito de mecanismos de memória celular (também referida por memória epigenética) ver, por exemplo, os artigos de Maurange e Paro (2002) e de Fantappié (2013), mais geral e didático.
}

Horizontes Antropológicos, Porto Alegre, ano 22, n. 46, p. 425-453, jul./dez. 2016 
Podemos interpretar a empreitada das pesquisadoras como uma tentativa de recuperar o primeiro Darwin: aquele que lançou mão da ideia de seleção natural, mas não descartou as ideias lamarckistas, e que afirmou que um hábito poderia se transformar em instinto (Darwin, 2004b). E também buscam dar resposta para o grande vazio da teoria darwinista (e neodarwinista) no tocante à compreensão do surgimento do cérebro humano por mutação e seleção natural, buscando desenvolver o que Darwin (2004b) já havia postulado, isto é, que esse órgão se formou sob pressão seletiva da própria cultura. ${ }^{8}$

Apesar de reconhecerem a novidade que as mutações epigenéticas representam no que tange às possibilidades de inter-relação entre as dimensões cultural e biológica, as autoras se apoiam em princípios já bastante difundidos entre os biólogos, como a ideia de que as práticas culturais são adaptativas. E como práticas culturais poderiam se inscrever nos genes enquanto características genéticas se estabilizariam em hábitos? Jablonka e Lamb respondem que através do efeito de memória celular e de outros mecanismos epigenéticos, úteis para explicar - por exemplo - as preferências alimentares, que podem tanto ser supostamente transmitidas geneticamente como induzidas pelo ambiente. Esse seria o caso do gosto que manifestam algumas crianças por alimentos que compuseram a dieta de suas mães enquanto grávidas. As pesquisadoras argumentam, enfim, reunindo ideias e pesquisas desenvolvidas por outros geneticistas, que um hábito adquirido pode se tornar hereditário.

O imunologista australiano Ted Steele concluiu de suas experiências que, em células somáticas responsáveis pela produção de anticorpos, as moléculas de DNA originais são cortadas, alteradas, coladas, desdobradas, para dar origem a linhas de células somáticas com DNAs diferentes, produtoras de diversos anticorpos. Há então, segundo Steele, um processo de seleção natural entre tais células, e as mais úteis passam a ser as mais numerosas. Steele sugere então que essa sequência selecionada pode ser carregada por vírus até as células que formam os gametas, passando assim à descendência, numa clássica materialização da herança dos caracteres adquiridos de Lamarck.

Waddington sugeriu a existência de um processo que denominou "assimilação genética". Quando animais se deparam com situações novas, tendem a superar as dificuldades através do aprendizado; se o comportamento

8 Ideia notoriamente endossada e bem defendida por Clifford Geertz (1978).

Horizontes Antropológicos, Porto Alegre, ano 22, n. 46, p. 425-453, jul./dez. 2016 
que daí surgir, decorrente do investimento desses indivíduos na tentativa de adaptação, tiver sucesso, as novas mudanças orgânicas que surgirem com o passar do tempo, e que "mimetizarem" o comportamento aprendido, serão também selecionadas e, com o tempo, poderão se tornar instintivas, tornando o aprendizado desnecessário. Teria sido então, segundo as autoras, esse processo, por meio do qual a base orgânica genética assimila o que foi desenvolvido por aprendizado, que teria desenvolvido a faculdade simbólica humana e sua sede, a mente. Para Jablonka e Lamb, a epigenética se mostra assim rica de oportunidades para uma complexificação da teoria evolucionista. Já para Richard Francis, embora a epigenética seja também uma grande novidade, ela teria apenas um potencial papel renovador do entendimento do processo da embriogênese. Se a epigenética, por um lado, redimensiona o poder pré-formacionista dos genes, por outro lado, ao lhes conferir o papel de charneira entre o "meio" interno e o "meio externo", torna essas moléculas ainda mais poderosas.

\section{Controvérsia infinda}

Os críticos do pré-formacionismo atual observam que o neodarwinismo fez dos genes resposta para tudo, mesmo sem esclarecer como eles estariam implicados nos processos em que atuariam. Hoje, o pressuposto de que o genoma funciona como um código e que a embriogênese e outros processos do organismo vivo decorrem da sua decodificação pela célula como um todo é aceito pela maior parte da comunidade científica, mesmo que só uma pequena parcela de tantos processos seja conhecida. Algumas hipóteses - como no exemplo do já referido "dogma da biologia" - já são aceitas como teorias experimentalmente comprovadas antes de serem evidenciadas. Os pré-formacionistas fazem portanto algo equivalente ao que os epigenistas faziam antes, ao trabalharem com noções vagas, sem demonstração experimental. Um dos críticos do pré-formacionismo contemporâneo, o antropólogo Tim Ingold, argumenta que, para o senso comum, informação é o conteúdo de uma mensagem, mas para a teoria da informação (desenvolvida, nos anos 1940, por Norbert Wiener, John von Neumann e Claude Shannon) a informação não está associada a nenhum conteúdo semântico específico. Como o DNA do genoma não codifica nada, não haveria, portanto, mensagem. Para Ingold (2004, p. 215, tradução nossa), "essa visão foi inteiramente perdida pelos biólogos

Horizontes Antropológicos, Porto Alegre, ano 22, n. 46, p. 425-453, jul./dez. 2016 
moleculares que, tendo percebido a molécula de DNA como a forma de informação digital num sentido teórico e informacional, imediatamente passaram à conclusão de que o código poderia ser tratado como um código de conteúdo semântico". O autor conclui assim que "o genótipo humano é uma fabricação da imaginação científica moderna" (Ingold, 2004, p. 215, tradução nossa).

Podemos complementar afirmando que os genes cumprem dessa forma uma função imaginária semelhante à do princípio vital ou da enteléquia dos vitalistas, o que permite aproximar sua concepção daquela, descrita por Canguilhem et al. (2003) para o pré-formacionismo dos séculos XVII e XVIII, que postulava a existência de um homúnculo dentro do ovo, cujo crescimento redundaria em um novo ser. Outra maneira de colocar a questão é assinalar que os pré-formacionismos, seja aquele que antes postulava a existência de um protótipo que apenas cresceria para originar um novo organismo, seja aquele que agora acredita na tradução de um código que guarda todas as informações necessárias ao surgimento do novo ser, partem do princípio de que o ovo é uma unidade autossuficiente, um sistema fechado em relação ao seu entorno, que depende de poucos processos físico-químicos para sua manutenção. A epigenética vem dar justamente um novo sentido à epigênese.

Richard Francis acredita que a epigenética encerra definitivamente a discussão entre pré-formação e epigênese. Argumenta que os epigenistas não haviam conseguido demonstrar seus argumentos de forma suficientemente científica, ficando suas ideias envoltas por uma aura mística, vitalista; algo que abriria espaço, no mínimo, para a pressuposição da existência de um "plano" ou "desenho inteligente". Com as pesquisas em epigenética, ocorre uma reformulação do papel e mesmo da definição de genes, ${ }^{9}$ pois é apenas uma pequena parte deles que funciona de acordo com sua atribuição oficial

9 Um dos efeitos das pesquisas ligadas ao conhecido Projeto Genoma Humano, iniciado na década de 1990, foi a surpreendente constatação de que uma imensa porção do material genético dos seres vivos é composta por genes não codificantes, i.e., a maior parte do DNA tem função diferente daquela de produzir proteínas. Essa parcela não codificante vem tendo sua importância reconhecida com o desenrolar de novos experimentos (Rabinow, 2002, p. 138). Paralelamente ao Projeto Genoma Humano, assiste-se a grande impulso nas pesquisas sobre memória celular e "herança epigenética", iniciadas na década de 1970, com implicações para os empreendimentos em clonagens, projetos de engenharia genética e para a expectativa da cura de muitas doenças. As limitações do Projeto Genoma Humano ensejaram a criação de um outro consórcio, do qual participam empresas e cientistas do Reino Unido, Alemanha e França, envolvidos no já mencionado Projeto Epigenoma Humano.

Horizontes Antropológicos, Porto Alegre, ano 22, n. 46, p. 425-453, jul./dez. 2016 
de sintetizadores de proteína. Uma grande parte deles coordena as funções da célula e do organismo, uma vez que se começa a admitir que o interior do núcleo onde o material genético está localizado é sensível às informações que chegam do exterior. Os genes, tal como vistos pela epigenética, não podem ser mais considerados software, programas de ação, diz Francis, devendo ser entendidos antes como hardware - metáfora mais fiel à dupla condição de instrutores e instruídos, ao mesmo tempo. O desenvolvimento não é algo completamente programado e a diferenciação celular é um processo que resulta da interação da célula com o ambiente externo.

Para o autor, então, as mutações epigenéticas podem, com toda certificação científica, substituir ideias pouco claras tais como "força vital" ou "enteléquia". Uma experiência que pretende contradizer a existência dessas figuras obscuras é a do toque de uma agulha sobre a membrana de um óvulo de ouriço-do-mar: o toque desencadeia um processo de embriogênese e o óvulo não fecundado dá origem a um ouriço normal. Para os cientistas, o óvulo interpreta a perfuração como a entrada de um espermatozoide e inicia sua divisão, e o local tocado pela agulha passa a ser o eixo equatorial do zigoto, que se desenvolve orientado pelos polos norte e sul, normalmente, como se tivesse havido fecundação. Se, num estágio mais avançado de embriogênese, células forem trocadas de lugar, em experimento de laboratório, nada de anormal acontece. Os cientistas observaram que essas células deslocadas se comportam situacionalmente e não como se possuíssem informações substantivas sobre que parte do embrião irão formar. Além disso, puderam testar que as células-tronco humanas podem induzir a desdiferenciação ${ }^{10}$ de diferentes tipos de células já especializadas graças a uma reprogramação de natureza epigenética, pois a estrutura dos genes permanece inalterada. Em laboratório percebeu-se ainda que células humanas cancerosas voltaram a ser sãs quando introduzidas em tecidos sãos; observou-se também que, sob certas condições, a célula pode se desdiferenciar, isto é, voltar a funcionar como se fosse uma célula-tronco (Francis, 2011, p. 131-132). Então, para Francis (2011, p. 135), os pré-formacionistas de hoje é que parecem ocupar o lugar de místicos, antes

${ }^{10}$ A desdiferenciação acontece no caso de reparação de uma injúria, como na regeneração de membros amputados de anfíbios. Em mamíferos a desdiferenciação acontece apenas em resposta à injúria à cartilagem e ao sistema nervoso central. Atualmente, acredita-se que a desdiferenciação pode causar o câncer e, por isso mesmo, ser o caminho para se procurar formas de sua cura (Francis, 2011).

Horizontes Antropológicos, Porto Alegre, ano 22, n. 46, p. 425-453, jul./dez. 2016 
destinados aos vitalistas, quando argumentam que um zigoto humano seja um ser humano. $\mathrm{O}$ autor sustenta ainda que as experiências nas quais o tecido sadio induz a desdiferenciação e a cura de células cancerosas nele transplantadas contradizem inteiramente as expectativas dos pré-formacionistas, para quem o que está fora do ovo não poderia contribuir para a formação do ser, pois o desenvolvimento (do ovo) seria "apenas" um crescimento do que já lá está de forma latente (Francis, 2011, p. 133).

A suspeita levantada por Gregory Bateson, no fim dos anos 1970, de que as ideias lamarckistas foram rechaçadas precocemente e que o dogma central da biologia não era uma ideia tão inquestionavelmente evidente quanto deveria ser para poder ascender ao olimpo dos dogmas é hoje objeto explícito de investigação da epigenética. Bateson, ao refletir sobre a possibilidade de se pensar, em conjunto, os processos biológicos e os processos mentais/culturais, considerou que há aleatoriedade tanto quanto conservação de estruturas preexistentes no contexto da evolução biológica e também no do aprendizado. $\mathrm{O}$ autor propôs, então, que não só a mutação aleatória, tal como aceita pelos neodarwinistas, mas também o mecanismo do uso e desuso, conhecido princípio lamarckista, seriam constitutivos da lógica natural capaz de explicar a forma pela qual a evolução orgânica ocorre. Analogamente, os processos mentais/culturais (a aprendizagem, por exemplo) também seriam constituídos, ao mesmo tempo, de aspectos criativos e tautológicos. O pensamento e a vida envolveriam sempre duas dimensões: uma estocástica, responsável pelo surgimento do novo, do inesperado, e outra conservativa, que propiciaria a perpetuação, por repetição, das formas antigas e já comprovadamente úteis (Bateson, 1986).

Bateson, portanto, acreditava que, em alguma medida, as ideias formuladas por Lamarck poderiam ter valor explicativo para o entendimento das transformações das formas vivas, a despeito do franco descrédito com que foram descartadas pelos neodarwinistas. Para ele, tais ideias seriam aceitáveis no concernente às mudanças somáticas momentâneas (como a "aclimatação"), mas estas não teriam capacidade de ser incorporadas diretamente à bagagem genética e consequentemente de passarem à descendência. Bateson, conjugando as duas proposições, tratadas usualmente como excludentes pelos biólogos ao longo do século XX, considerou a possibilidade de existir um mecanismo biológico que gerasse uma "genocópia", isto é, um genótipo que surgisse a partir de um processo aleatório, como qualquer mutação genética, 
mas que fosse selecionado graças ao fato de ensejar um fenótipo que imitasse uma mudança somática positiva precedente. ${ }^{11}$

Bateson não tinha dúvida de que o mundo biológico parecia ser produto de uma evolução lamarckista. Entretanto, para ele, se o tipo de adaptação lamarckista fosse o dispositivo corriqueiro na natureza, sem a fundamental contribuição do evento aleatório e criativo, teria ocorrido grande perda da flexibilidade dos organismos (Bateson, 1986, p. 156-157), o que o afasta definitivamente dos enunciados de Lamarck. Para o antropólogo haveria "então dois grandes sistemas estocásticos que estão parcialmente em interação e parcialmente isolados um do outro. Um sistema está dentro do indivíduo e é chamado de aprendizado; o outro é imanente na hereditariedade e nas populações e é denominado evolução" (Bateson, 1986, p. 155, grifo do autor).

No tocante aos mecanismos vivos, Bateson concebeu a existência de dois níveis lógicos e hierarquicamente relacionados. No nível mais alto haveria informações sobre o estabelecimento dos limites de variação dentro dos quais o organismo seria capaz de mudar sua aparência e seu funcionamento. Acreditava que o DNA não encerraria propriamente mensagens relativas a características concretas e sim informações sobre sistemas relacionais dessas características, constituindo o nível lógico mais elevado e tendo a capacidade de se reproduzir por hereditariedade. O que um ser herdaria de seus ancestrais seria a capacidade para expressar certa característica e não a característica em si. Bateson entendia que o comando genético habilitaria o organismo à flexibilidade em suas alterações somáticas, devendo, por isso, ser classificado, em termos lógicos, como hierarquicamente superior às alterações corporais e à capacidade do organismo em atingir aprendizado. Seria próprio daquele nível lógico que Bateson considerou mais elevado que suas alterações fossem hereditárias e ocorressem aleatoriamente. "Sem o aleatório, não pode haver coisas novas", afirmou o autor (Bateson, 1986, p. 153), para quem o processo de epigênese $\mathrm{e}^{12}$ constituiria uma tautologia, por ser um processo basicamente conservativo.

\footnotetext{
11 Isso já havia sido pensado por Waddington nas suas formulações sobre “assimilação genética” (Bateson, 1986, p. 167).

12 A palavra "epigênese", nesse texto de Bateson, significa ontogênese.
} 


\section{Considerações finais}

A seção de "Comentários" de um dos números de 2014 da revista Nature revê as linhas gerais do debate sobre a magnitude da transformação que os fenômenos epigenéticos podem representar para a síntese moderna. $\mathrm{O}$ artigo expõe as visões dos dois grupos de pesquisadores que se opõem quanto à necessidade de reformulação da teoria hegemônica. No artigo, Gregory Wray e Hopi Hoekstra (cf. Laland et al., 2014) afirmam, juntamente com outros cientistas, que a epigenética enriquece mas não questiona a atual teoria evolucionária, ao passo que Kevin Laland, Eva Jablonka e outros biólogos (cf. Laland et al., 2014) defendem sua total reformulação. Estes últimos propõem uma nova teoria, denominada extended evolutionary synthesis (EES), que recupera pressupostos lamarckistas e clama pela revisão do dogma central proposto por Crick (cf. Fodor et al., 2008; Godfrey-Smith, 2007), nos termos vistos acima. $\mathrm{O}$ artigo evidencia que a discussão tem envolvido não só geneticistas, como Jablonka, mas também, a exemplo de Hoekstra, pesquisadores da biologia do desenvolvimento, ${ }^{13}$ designação alternativa para a embriologia vista sob a ótica da síntese moderna.

$\mathrm{O}$ incremento das investigações sobre desenvolvimento ensejou recentemente o surgimento de um campo de pesquisa denominado "evo-devo". ${ }^{14}$ Os cientistas afiliados à evo-devo retomam as disposições iniciais das ciências da vida, ligando as elaborações teóricas já acumuladas sobre evolução das espécies àquelas reunidas a propósito do desenvolvimento ontogenético ou embriológico. Nota-se aí então a permanência da distinção semântica, analisada por Canguilhem et al. (2003), ocorrida no século XIX, quando o termo "evolução" passou a não mais significar desenvolvimento, vindo, no século $\mathrm{XX}$, a servir ao neodarwinismo para designar a genética de populações e suas mudanças ao longo do tempo. Durante este início do século XXI, a diferença entre os termos se mantém, mas, associados por um hífen, passam agora

13 Conforme o Oxford Dictionary of Biology (2008), as subdisciplinas biologia do desenvolvimento e embriologia constituem a área da biologia que estuda os seres individualmente, sobretudo em suas fases embrionárias, incluindo a atuação dos genes responsáveis pelo crescimento e a maturação dos animais até seu nascimento.

${ }^{14}$ Contração de "evolução do desenvolvimento". Para um histórico sobre o surgimento desse campo de pesquisa ver Hoekstra e Coyne (2007).

Horizontes Antropológicos, Porto Alegre, ano 22, n. 46, p. 425-453, jul./dez. 2016 
a (re)unir os estudos sobre evolução àqueles relativos ao desenvolvimento/ embriologia.

Se confrontarmos a análise de Canguilhem com a visão de Tim Ingold a propósito de Darwin, nota-se, sem surpresa, que há concordância a respeito do fato de o pensamento do naturalista ser um marco para o crescente interesse nos estudos sobre evolução, em detrimento daqueles dedicados à embriogênese. Mas, diferentemente de Canguilhem, para quem o caráter inovador da contribuição de Darwin o torna um pesquisador sem predecessores, Ingold (2004, p. 212) vê no cientista vitoriano um homem de seu tempo - racista, racionalista e imbuído do evolucionismo de Spencer - e que, nessa condição, veio a reforçar a crença na coexistência de dois processos de evolução distintos: um que teria originado os seres humanos, a partir de seus ancestrais simiescos, e outro, característico da cultura ou história, que teria possibilitado à humanidade primitiva atingir a civilização. Ingold (2004, p. 219) considera ainda que o naturalista não pôde escapar da maneira de pensar que trata cada criatura viva como uma entidade cuja natureza essencial é prefigurada antecipadamente à sua existência concreta. Para Ingold (2004, p. 215), os neodarwinistas só fizeram aprofundar as características pré-formacionistas do patrono.

As críticas de Ingold vão no mesmo sentido daquela formulada por Francis e se contrapõem à ideia da metáfora dos genes como software, como se os organismos resultassem diretamente de sua ação, de forma análoga ao resultado final de um código decifrado. A psicóloga Susan Oyama (2000) também se coloca criticamente frente às teorias mecanicistas/pré-formacionistas, que vêm vigorando na biologia pós-Darwin, e propõe a developmental systems theory - DST (cf. Oyama; Griffiths; Gray, 2001, p. 1-11), em busca de um modelo menos polarizado entre o exterior e o interior das células, entre núcleo e citoplasma celulares e também entre organismos e seu meio. Há muitos indícios de que as novas proposições, a exemplo da evo-devo e da DST, que se manifestam como refinamentos do neodarwinismo, ou ainda, a EES, que se coloca como uma alternativa ao dogma vigente nas ciências da vida, configuram uma busca pela compreensão da totalidade dos fenômenos da vida, que pode ser entendida como um retorno à busca pela unidade vitalista.

Se Ingold é, por um lado, um entusiasta das tentativas de superação das barreiras disciplinares entre antropologia (social/cultural) e biologia (cf. Silva, 2006), por outro lado, é um crítico irredutível do neodarwinismo, rejeitando a noção filogenética de evolução a favor de uma ideia topológica 
de desenvolvimento. Também se coloca como uma exceção internamente ao campo da própria antropologia atual, por considerar a noção de cultura, ainda tão cara e popular entre antropólogos, obsoleta.

Para ele, tentar ir além dos limites disciplinares exige que os antropólogos pensem as formas culturais como aspectos das formas vivas, reconhecendo que aquelas aparecem dentro de uma teia da vida em atividade conjunta. Os biólogos, por sua vez, deveriam passar a entender evolução topologicamente, como uma tapeçaria que se desdobra, e não como quanta de informações bioquímicas que passam através das gerações por organismos individuais. As formas de vida não seriam então nem genética nem culturalmente preconfiguradas e emergiriam como propriedades da dinâmica da auto-organização.

O momento parece propício a uma aproximação heurística, já iniciada por Bateson e mantida por Ingold, entre as humanidades e as ciências naturais, ou a uma reconsideração, dentro do pensamento ocidental, do estatuto da sua "natureza". Entretanto a distância parece permanecer invencível enquanto a unidade se fizer em torno da noção de evolução sustentada pelo neodarwinismo.

\section{Referências}

ÅGREN, J. A.; STEPHEN, I. W. Co-evolution between transposable elements and their hosts: a major factor in genome size evolution?. Chromossome Research, Oxford, v. 19, n. 6, p. 777-786, 2011.

BATESON, G. Mente e natureza. Rio de Janeiro: Francisco Alves, 1986.

CANGUILHEM, G. O conhecimento da vida. Rio de Janeiro: Forense Universitária, 2012.

CANGUILHEM, G. et al. Du développement à l'évolution au XIX siècle. Paris: PUF, 2003.

DARWIN, C. A origem das espécies. São Paulo: Martin Claret, 2004a.

DARWIN, C. A origem do homem e a seleção sexual. Belo Horizonte: Itatiaia, 2004b.

Horizontes Antropológicos, Porto Alegre, ano 22, n. 46, p. 425-453, jul./dez. 2016 
DUARTE, L. F. O paradoxo de Bergson: diferença e holismo na antropologia do Ocidente. Mana, Rio de Janeiro, v. 18, n. 3, p. 417-448, 2012.

FANTAPPIÉ, M. Epigenética e memória celular. Carbono, n. 3, 2013. Disponível em: <http://revistacarbono.com/artigos/03-epigenetica-ememoria-celular-marcelofantappie/>. 2013. Acesso em: 15 abr. 2015.

FODOR, J. et al. Against Darwinism. Mind \& Language, Oxford, v. 23, n. 1, p. 1-24, 2008.

FRANCIS, R. Epigenetics: the ultimate mystery of inheritance. New York: Norton \& Company, 2011.

GEERTZ, C. A interpretação das culturas. Rio de Janeiro: Zahar, 1978.

GODFREY-SMITH, P. Is it a revolution? Biology \& Philosophy, Dordrecht, v. 22, n. 3, p. 429-437, 2007.

GUSDORF, G. Introduction aux Sciences Humaines: essai critique sur leurs origines et leur développement. Paris: Ophrys, 1974.

HARAWAY, D. Crystals, fabrics, ans fields: metaphors that shape embryos. Berkeley: North Atlantic Books, 2004.

HOEKSTRA, H. E.; COYNE, J. A. The locus of evolution: EVO-DEVO and the genetics of adaptation. Evolution, Hoboken, v. 61, n. 5, p. 995-1016, 2007.

HOLLIDAY, R. Epigenetics: a historical overview. Epigenetics, Philadelphia, v. 1, n. 2, p. 76-80, 2006.

INGOLD, T. An anthropologist looks at biology. Man, London, v. 25, n. 2, p. 208-229, 1990.

INGOLD, T. Beyond biology and culture. The meaning of evolution in a relational world. Social Anthropology, Cambridge, v. 12, n. 2, p. 209-221, 2004.

INGOLD, T. Sobre a distinção entre evolução e história. Antropolítica, Niterói, n. 20, p. 17-36, 2006. 
INGOLD, T. Prospect. In: INGOLD, T.; PALSSON, G. (Ed.). Biossocial becomings: integrating social and biological anthropology. Cambridge: Cambridge University Press, 2013. p. 1-21.

JABLONKA, E.; LAMB, M. Evolução em quatro dimensões. São Paulo: Companhia das Letras, 2010.

LALAND, K. et al. Does evolutionary theory need a rethink?. Nature, London, v. 514, n. 7521, p. 161-164, 2014.

LANDECKER, H.; PANOFSKY, A. From social structure to gene regulation, and back: a critical introduction to environmental epigenetics for sociology. Annual Review of Sociology, Palo Alto, v. 39, p. 333-357, 2013.

LATOUR, B. Ciência em ação: como seguir cientistas e engenheiros sociedade afora. São Paulo: Ed. Unesp, 2000.

LIPPMANN, Z. et al. Role of transposable elements in heterochromatin and epigenetic control. Nature, London, v. 430, n. 6998, p. 471-476, 2004.

MAURANGE, C.; PARO, R. A cellular memory module conveys epigenetic inheritance of hedgehog expression during Drosophila wing imaginal disc development. Genes \& Development, Cold Spring Harbor, n. 16, p. 26722683, 2002. Disponível em: <http://www.genesdev.org/cgi/doi/10.1101/ gad.242702>. Acesso em: 13 mar. 2015.

OXFORD DICTIONARY OF BIOLOGY. Oxford: Oxford University Press, 2008.

OYAMA, S. Evolution's eye: a systems view of the biology-culture divide. Durham: Duke University Press, 2000.

OYAMA, S.; GRIFFITHS, P.; GRAY, R. (Ed.). Cycles of contingency: developmental systems and evolution. Cambridge: Massachusetts Institute of Technology Press, 2001.

RABINOW, P. Antropologia da razão: ensaios de Paul Rabinow. Rio de Janeiro: Relume Dumará, 2002. 
REILL, P. H. Vitalizing nature in the enlightenment. Berkeley: University of California Press, 2005.

SILVA, G. A sociobiologia e a crítica dos antropólogos. ComCiência: Revista Eletrônica de Jornalismo Científico, n. 80, 2006.

SILVA, G. Os antropólogos devem, sim, falar de biologia: a contribuição de Tim Ingold para uma reflexão sobre o darwinismo hoje. In: STEIL, C. A.; CARVALHO, I. (Org.). Cultura, percepção e ambiente: a contribuição de Tim Ingold para uma mudança de paradigma. São Paulo: Terceiro Nome, 2012. p. 121-136.

TOST, J. DNA methylation: an introduction to the biology and the diseaseassociated changes of a promising biomarker. Molecular Biotechnology, Totowa, v. 44, n. 1, p. 71-81, 2010. 